\title{
POLYPHENOL CONTENT AND ANTIOXIDANT ACTIVITY OF MAQUI (Aristotelia chilensis [MOLINA] STUNTZ) DURING FRUIT DEVELOPMENT AND MATURATION IN CENTRAL CHILE
}

\author{
Carolina Fredes $^{1 *}$, Gloria Montenegro ${ }^{1}$, Juan Pablo Zoffoli ${ }^{1}$, Miguel Gómez ${ }^{1}$, and Paz Robert ${ }^{2}$
}

\begin{abstract}
Maqui (Aristotelia chilensis [Molina] Stuntz, Elaeocarpaceae) is a Chilean native species which produces small berries that are mainly collected from the wild. The health benefits of maqui fruit are attributed to their high polyphenol content as well as their wide variety of anthocyanins and flavonols. One of the main factors that affect the polyphenol content in fruit is the maturity stage at harvest. The objective of this study was to determine total phenol and total anthocyanin content and antioxidant activity (by ferric reducing ability of plasma [FRAP] assay) of maqui fruits harvested at different fruit maturity stages from two wild populations located in Central Chile. Each maturity stage was determined by days from fruit set, berry size, and soluble solids. Total phenol content declined while total anthocyanin content increased from the green to light red stage. Nevertheless, both total phenol and anthocyanin content increased from the light red to dark purple stage. The highest anthocyanin content and antioxidant activity was found in the late maturity stage (dark purple). The results show that ripening in maqui fruit can be expected with 1100 growing degree-days (91 d after fruit set) in Central Chile. At this moment of harvest, fruits with $18-19^{\circ}$ Brix have the highest anthocyanin content and antioxidant activity (FRAP). This study constitutes the first advances in the understanding of maqui fruit ripening and corresponding antioxidant activity.
\end{abstract}

Key words: FRAP, maturity stages, ripening, total anthocyanins, total phenols.

$S^{n+\infty}$ tudies of polyphenols in maqui (Aristotelia chilensis [Molina] Stuntz, Elaeocarpaceae) fruits show great potential as a source of natural antioxidants (Fredes, 2009). These fruits have higher total phenol content and antioxidant activity than other species recognized for their high polyphenol content such as blackberries (Rubus spp.), blueberries (Vaccinium corymbosum L.), raspberries (Rubus idaeus L.), strawberries (Fragaria xananassa Duchesne ex Rozier) and others (MirandaRottmann et al., 2002; Araya et al., 2006). Maqui fruit phenolic extracts have also shown antioxidant activity in-vivo (Céspedes et al., 2008). The main compounds in maqui fruits are phenolic acids, flavonols (quercetin, rutin, myricetin), flavanols (catechins, epicatechin), and eight anthocyanins (Escribano-Bailón et al., 2006; Céspedes et al., 2010; Schreckinger et al., 2010; Rojo et al., 2012).

Even though advances in polyphenol characterization of maqui are vast, no data on the development of phenolic compounds and antioxidant activity during the process of

${ }^{1}$ Pontificia Universidad Católica de Chile, Facultad de Agronomía e Ingeniería Forestal, Vicuña Mackenna 4860, Macul, Santiago, Chile. *Corresponding author (cpfredes@uc.cl).

${ }^{2}$ Universidad de Chile, Facultad de Ciencias Químicas y Farmacéuticas, Av. Vicuña Mackenna 20, Santiago, Chile.

Received: 29 March 2012.

Accepted: 14 September 2012. fruit maturation and ripening have been reported. Because anthocyanins are the focus of interest in maqui fruit it is necessary to establish the best maturity index in order to optimize the anthocyanin content in maqui fruit.

Maqui is a Chilean native species that grows naturally as an evergreen bush or tree from Limarí $\left(30^{\circ} \mathrm{S}\right.$ lat, Coquimbo Region) to Aysén ( $45^{\circ} \mathrm{S}$ lat, Aysén del General Carlos Ibáñez del Campo Region), Chile, from the coast to $2000 \mathrm{~m}$ a.s.l. (Rodríguez et al., 1983). It is a pioneer species (that colonizes disturbed environments) and is considered a woody species with great capacity for regeneration in pine forests of central and southern Chile (Gómez et al., 2009), forming wild populations called "macales". In continental Chile it appears abundantly after logging of native forests and it is only considered a weed in the Juan Fernández Archipelago, where it covers significant areas, displacing native flora (Matthei, 1995; Dirnbock, 2003). In native forests in Central Chile, maqui is a secondary species where populations of quillay (Quillaja saponaria Molina), litre (Lithraea caustica [Molina] Hook. \& Arn.) and peumo (Cryptocarya alba [Molina] Looser) are predominant (Gajardo, 1994). Maqui fruits are mainly collected from the wild from December to January (Montenegro, 2002). Maqui commercial crops do not exist yet. For this reason it is necessary to establish agronomic parameters for their selection and cultivation.

In recent years, the search of genotypes with health 
benefits has been considered an important issue in the study of species recognized for their high anthocyanin content like strawberries (Capocasa et al., 2008a; 2008b), blackberries (Cuevas-Rodríguez et al., 2010) and cranberries (Vaccinium macrocarpon Aiton) (Brown et al., 2012). Thus, the knowledge of the evolution of anthocyanin content during the fruit development and maturity is essential to select the best maqui genotypes according to high anthocyanin content (Vvedenskaya and Vorsa, 2004; Kulkarni and Aradhya, 2005; Wang et al., 2009). In this context the aim of this study was to determine changes of polyphenol content and the corresponding antioxidant activity of maqui during fruit maturation and ripening in Central Chile.

\section{MATERIALS AND METHODS}

\section{Plant material}

Maqui fruits were collected from two wild populations located in the Libertador General Bernardo O'Higgins Region of Central valley of Chile (Figure 1). Both the Paredones (34 $36^{\prime} \mathrm{S}, 76^{\circ} 53^{\prime} \mathrm{W}$ ) and Rancagua (34 $7^{\circ}$ ' $\mathrm{S}, 70^{\circ} 51^{\prime} \mathrm{W}$ ) sites of maqui fruit sampling were located $108.6 \mathrm{~km}$ apart and correspond to examples of wild populations placed most close to the coast (Paredones) and in the middle valley (Rancagua).

During flowering, female individuals were identified and labeled. At least $50 \%$ of female individuals in each site of sampling were selected. Very young individuals and plants with leaf damage were discarded. Maqui fruit samples (100 fruits) were taken randomly from five individuals per site of sampling at 15-20 d intervals to get five different maturity stages starting at the end of October $(21 \mathrm{~d}$ from fruit set). Fruits were transferred in a cooler $\left(6^{\circ} \mathrm{C}\right)$ during the day of each harvest to the laboratory for analysis. Then, samples of each individual

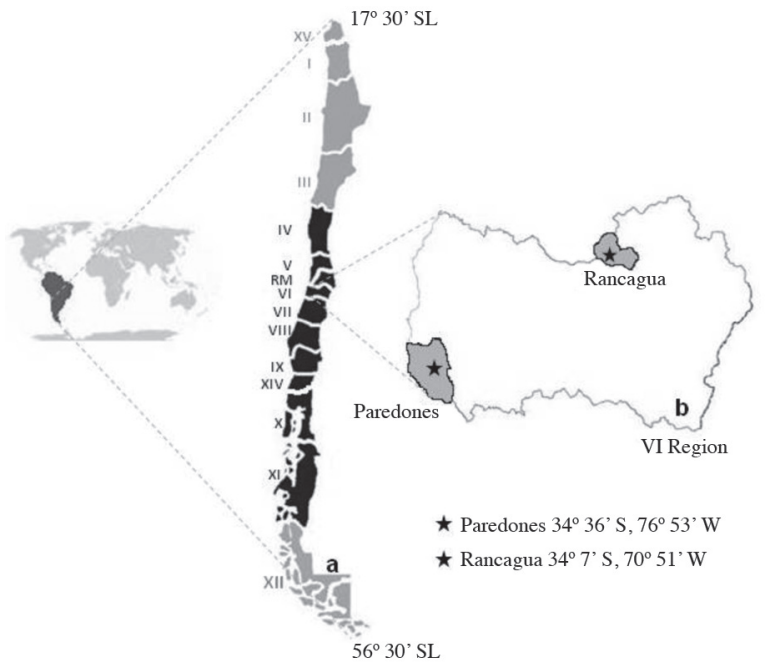

Figure 1. Distribution of maqui in Chile (a). Sites of maqui fruit sampling and their georeferences in the Libertador General Bernardo O'Higgins Region (VI Region) of Central Chile (b). were separated in two groups for analytical procedures. All the parameters were analyzed in triplicate.

Berry weight was determined by the mean weight of 30 fresh fruits (Vvedenskaya and Vorsa, 2004). Slurries were used to determine total soluble solid (SS) content by refractometry (ATAGO-Spectrum Technologies, Plainfield, Illinois, USA).

\section{Climatic information}

Paredones and Rancagua minimum and maximum air daily temperatures, cumulative rainfall and growing degree-days were recorded from October to December (from flower full phase to fruit harvest) for 2010. This information was provided by Chilean Meteorological Service for weather stations closest to the respective sites of sampling.

\section{Determination of total phenols}

Samples for antioxidant analysis were prepared by using acidified methanol $(0.1 \% \mathrm{HCl})$ method described by Rodarte Castrejón et al. (2008). A grinded sample (1.5 g) was mixed vigorously with $6 \mathrm{~mL}$ of acidified methanol $(0.1 \% \mathrm{HCl})$ for $1 \mathrm{~h}$ and centrifuged for $15 \mathrm{~min}$ at $3000 \mathrm{rpm}$. Supernatant was collected in a $25 \mathrm{~mL}$ volumetric flask. The residue was treated again twice with $6 \mathrm{~mL}$ acidified methanol and 15 min centrifugation. Supernatants were collected and standardized to a final volume of $25 \mathrm{~mL}$. Total phenols (TP) were determined by Folin Ciocalteu method (Singleton and Rossi, 1965). Maqui fruit extract, distilled water, and Folin-Ciocalteu's phenol reagent were added and the mixture was incubated for $3 \mathrm{~min}$, at which time $20 \%$ sodium carbonate was added. After 30 min, the absorbance was measured in a spectrophotometer (Unicam UV/VIS ATI UNICAM, Cambridge, UK) at 765 nm. Gallic acid was used as the standard, according to a calibration curve $\left(133.8-428 \mu \mathrm{g} \mathrm{mL}^{-1} ; \mathrm{R}^{2}=0.9901\right)$. The results were expressed as grams of gallic acid equivalent (GAE) per kilogram fresh weight ( $\mathrm{g} \mathrm{GAE} \mathrm{kg}^{-1} \mathrm{fw}$ ).

\section{Determination of total anthocyanins}

Total anthocyanins (TA) were determined by differential pH method (Wrolstad, 1976) using a spectrophotometer (Unicam UV/VIS ATI UNICAM, Cambridge, UK). Absorbance of maqui fruit extract was measured at 515 and $700 \mathrm{~nm}$ in $\mathrm{pH} 1.0$ and 4.5 buffers respectively using $\mathrm{A}=(\mathrm{A} 515$ - A700) $\mathrm{pH} 1.0$ - (A515 - A700) pH 4.5 with a molar extinction coefficient of 26900 . Results were expressed as grams of cyanidin-3-glucoside equivalent per kilogram fresh weight (g cy-3-glu kg-1 fw).

\section{Determination of antioxidant capacity}

Antioxidant capacity (AA) was determined by ferric reducing ability of plasma (FRAP) method as described by Benzie and Strain (1996) using a spectrophotometer (Unicam UV/VIS ATI UNICAM, Cambridge, UK). Determination was conducted using three aqueous stock 
solutions containing $0.1 \mathrm{~mol} \mathrm{~L}^{-1}$ acetate buffer ( $\mathrm{pH} 3.6$ ), 10 mmol L-1 TPTZ [2,4,6-tris(2-pyridyl)-1,3,5-triazine] acidified with concentrated $\mathrm{HCl}(40 \mathrm{mM})$, and $20 \mathrm{mmol}$ $\mathrm{L}^{-1} \mathrm{FeCl}_{3}$. Stock solutions were combined $(10: 1: 1 \mathrm{v} / \mathrm{v} / \mathrm{v})$ to get the FRAP reagent just prior to analysis; $2.7 \mathrm{~mL}$ of FRAP reagent, $270 \mu \mathrm{L}$ of miliq $\mathrm{H}_{2} \mathrm{O}$ and $30 \mu \mathrm{L}$ of sample extract were mixed. After $10 \mathrm{~min}$, the absorbance was measured at $593 \mathrm{~nm}$. Aqueous standard solutions of $\mathrm{FeSO}_{4}$ $7 \mathrm{H}_{2} \mathrm{O}(0-1000 \mu \mathrm{M})$ were used for the calibration curve and the results were expressed as mmol of $\mathrm{Fe}^{2+}$ equivalent per kilogram fresh weight (mmol $\mathrm{E} \mathrm{Fe}^{2+} \mathrm{kg}^{-1} \mathrm{fw}$ ).

\section{Statistical analysis}

Results were expressed as the mean and standard deviation of the five individuals for each parameter in the five maturity stages per site of sampling. Calculations were performed with SAS 9.2 for Microsoft Windows (20022008, SAS Institute, Cary, North Carolina, USA). The significance between maturity stages for each parameter was calculated with a Tukey-HSD (Honest Significant Differences) multiple-comparison test ( $\mathrm{p} \leq 0.05)$.

\section{RESULTS AND DISCUSSION}

\section{Fruit development and phenolic maturation in two wild populations of Central Chile}

Due to the wide distribution of maqui in Chile, two sites of sampling in the same latitude $\left(34^{\circ} \mathrm{S}\right)$ were chosen for this study in order to minimize climatic incidences. However, slight differences between both sampling sites may be observed due to the maritime and altitude influence in these areas (Figure 1).

Flower phases were recorded during the first and second weeks of October for both fruit sampling sites the 2010. Fruits were harvested in 15-20 d intervals showing five different maturity stages. The names for each maturity stage were given according to the color that at least the $50 \%$ of the fruits showed at each time of harvest. The first (green I, $21 \mathrm{~d}$ from fruit set) and second (green II) stages were characterized by green fruits whereas the third stage was characterized by fruits that began to show red color (light red). The fourth (purple) and fifth (deep purple) stages consisted of purple fruits. Although the fruit set was observed first in Paredones, the fruit harvest in both sampling sites was during the same week. This is congruent with the minimum difference of the growing degree-days between both Paredones and Rancagua sampling site (Figure 2B). Maqui fruits from all analyzed individuals began to show dehydration a week after the fifth harvest stage indicating that this was the latest maturity stage.

As expected with natural ripening of maqui, the fruit weight of Rancagua and Paredones berries progressively increased from 10.2 to 21.1 and 10.8 to $21.7 \mathrm{~g}$ per 100 berries, respectively (Table 1). The highest increase in weight occurred between green II and light red stages with significant differences between both stages, where Rancagua fruits showed a higher increase in weight than Paredones fruits. Fruit weights were very similar for both sampling sites at the late maturity stage (deep purple) which correlates to the low rainfall typical of the spring and summer seasons in the region studied. Total rainfall in Paredones and Rancagua reached maximum values of 31 and $15.8 \mathrm{~mm}$ during the growing season, respectively (Figure 2C), and the latest rainfall was recorded on 24 November $(3.4 \mathrm{~mm})$ and 23 October $(12.4 \mathrm{~mm})$, respectively.

Maqui fruit weight was significantly lower than other species recognized as berries, such as cranberry (141.8 g per 100 berries) and calafate (Berberis buxifolia Lam., 32.4 g per 100 berries) (Arena and Curvetto, 2008; Celik
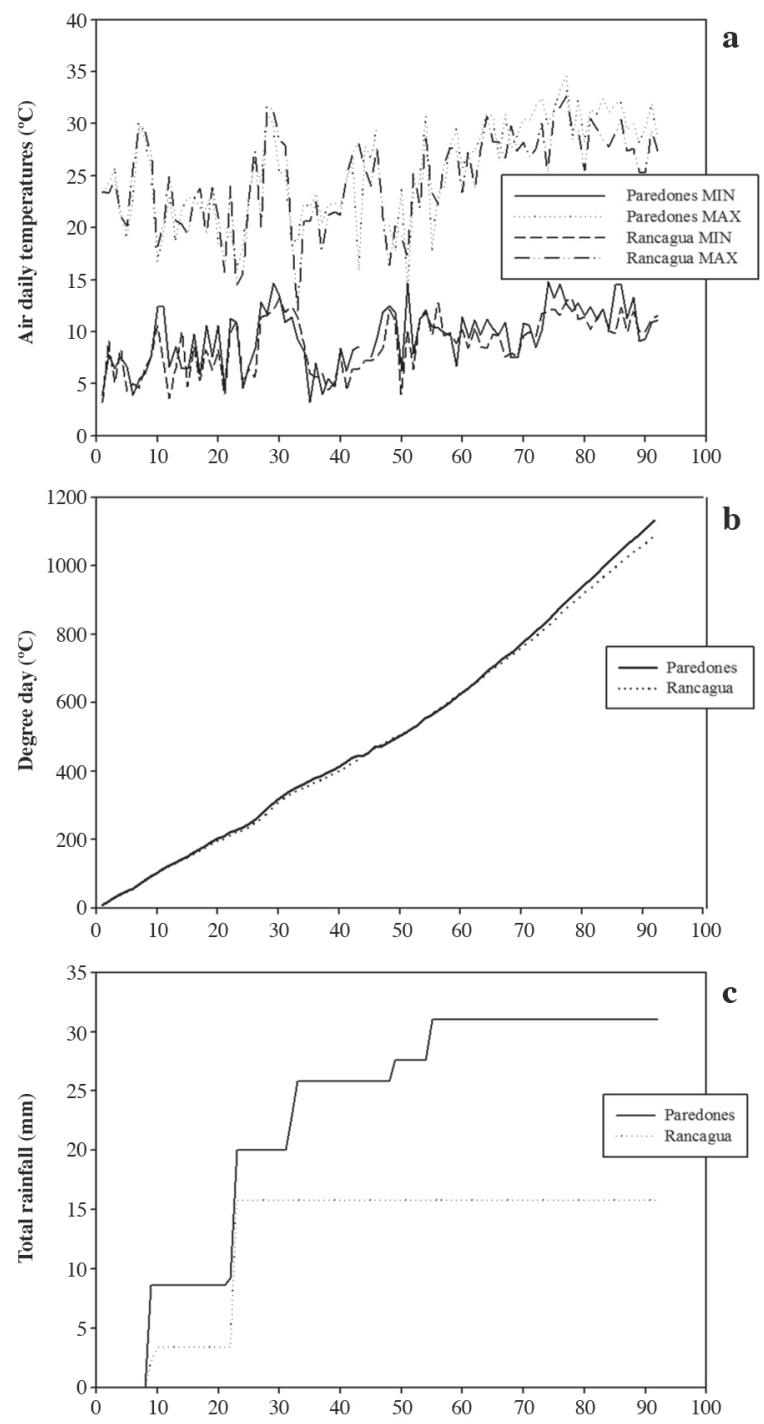

Figure 2. Climatic data for weather stations near Paredones $\left(34^{\circ} 36^{\prime} \mathrm{S}\right.$ $76^{\circ} 53^{\prime} \mathrm{W}$ ) and Rancagua $\left(34^{\circ} 7^{\prime} \mathrm{S}, 7^{\circ} 51^{\prime} \mathrm{W}\right)$ sites of maqui fruit sampling: (a) minimum and maximum air daily temperatures, (b) cumulative rainfall and (c) growing degree-days $\left(5^{\circ} \mathrm{C}\right.$ base) were recorded from October to December 2010. 
Table 1. Description of the selected maturity stages of maqui fruit harvested in Paredones and Rancagua.

\begin{tabular}{|c|c|c|c|c|c|c|}
\hline \multirow[b]{2}{*}{ Stage } & \multicolumn{2}{|c|}{ Days from fruit set } & \multicolumn{2}{|c|}{ Berry weight } & \multicolumn{2}{|c|}{ Soluble solids } \\
\hline & Paredones & Rancagua & Paredones & Rancagua & Paredones & Rancagua \\
\hline & & & $\longrightarrow \mathrm{g} \mathrm{pe}$ & ries $\longrightarrow$ & $\longrightarrow$ & - \\
\hline Green I & 21 & 21 & $10.8 \pm 0.7 \mathrm{a}$ & $10.2 \pm 2.1 \mathrm{a}$ & $5.4 \pm 0.2 \mathrm{a}$ & $5.0 \pm 0.2 \mathrm{a}$ \\
\hline Green II & 41 & 40 & $13.1 \pm 0.6 \mathrm{a}$ & $11.8 \pm 2.1 \mathrm{a}$ & $8.6 \pm 0.2 b$ & $7.8 \pm 0.3 b$ \\
\hline Light red & 61 & 60 & $17.8 \pm 2.5 b$ & $16.5 \pm 3.1 b$ & $13.5 \pm 0.2 \mathrm{c}$ & $12.6 \pm 0.5 \mathrm{c}$ \\
\hline Purple & 76 & 80 & $19.3 \pm 2.6 b c$ & $19.0 \pm 3.5 b c$ & $16.3 \pm 0.3 \mathrm{~d}$ & $15.8 \pm 0.2 \mathrm{~d}$ \\
\hline Dark purple & 91 & 95 & $21.7 \pm 2.5 c$ & $21.1 \pm 3.0 \mathrm{c}$ & $19.9 \pm 0.4 \mathrm{e}$ & $18.8 \pm 0.1 \mathrm{e}$ \\
\hline
\end{tabular}

Means and standard deviations belong to five individuals. Means in each column not followed by the same letter are significantly different ( $\mathrm{p} \leq 0.05$ )

et al., 2008). The comparison with these other fruits indicates that maqui fruit has a higher surface/volume ratio.

Soluble solids (SS) of Rancagua and Paredones fruits increased from 5.0 to 18.8 and 5.44 to $19.9^{\circ} \mathrm{Brix}$, respectively, during fruit maturation (Table 1) due to the accumulation of sugars. This increase was significantly different for each maturity stage, although comparable results for this variable was observed in both maqui fruit sampling sites. The similar air temperature conditions of both fruit sampling sites during the season of study (Figures 2A) could explain these results and the other parameters evaluated as discussed below. The lowest SS were obtained in the most immature fruits (green I) whereas the highest SS were obtained $91 \mathrm{~d}$ after fruit set. The results indicated that maqui fruit have more SS than other berry fruits such us blueberry (17.1 ${ }^{\circ}$ Brix), pomegranate (Punica granatum L.15.3 ${ }^{\circ}$ Brix), blackberry (11.8 ${ }^{\circ}$ Brix), raspberry (10.9 ${ }^{\circ}$ Brix) and cranberry $(9.3$ ${ }^{\circ}$ Brix) (Siriwoharn et al., 2004; Kulkarni and Aradhya, 2005; Celik et al., 2008; Rodarte Castrejón et al., 2008; Wang et al., 2009).

\section{Total phenols during maqui fruit development and} maturation

The main factors that affect the polyphenol content in fruits are genotype, environment, storage and processing, and stage at harvest. Fruits harvested at different maturity stages present different contents and types of polyphenols; in immature fruits proanthocyanidins are predominant while in mature fruits anthocyanins predominate (Vvedenskaya and Vorsa, 2004; Kulkarni and Aradhya, 2005; Wang et al., 2009). This first study in maqui fruit attempted to understand the main changes in phenolic compounds and antioxidant activity during the process of fruit maturation and ripening in order to establish the best maturity index for maqui fruit according to its anthocyanin content. For this reason, simple, reproducible and validated parameters for phenolic determination were used.

Folin Ciocalteu method is the most common assay for the estimation of TP in many fruits and foods (Mersmestein, 2008). Although this method overestimates the phenol content due to the presence of L-ascorbic acid (vitamin C) (Singleton and Rossi, 1965), maqui would not present this interference because vitamin $\mathrm{C}$ has not been detected in fruit according to Miranda-Rottmann et al. (2002). In this study the highest TP was recorded for Paredones in green II stage (9.95 $\left.\mathrm{g} \mathrm{GAE} \mathrm{kg}^{-1} \mathrm{fw}\right)$ and for Rancagua in green I stage (10.14 $\mathrm{g} \mathrm{GAE} \mathrm{kg}^{-1} \mathrm{fw}$ ) but there were not significant differences between the first and the late maturity stage (deep purple) (Figure 3). The high TP in the first maturity stages was similar to other species such as strawberry, cranberry, pomegranate, teaberry (Gaultheria procumbens L.), mangosteen (Garcinia mangostana Linn.), blueberry, and blackberry (Wang and Lin, 2000; Siriwoharn et al., 2004; Kulkarni and Aradhya, 2005; Celik et al., 2008; Rodarte Castrejón et al., 2008; Tosun et al., 2008; Pliszka et al., 2009; Pothitirat et al., 2009), which has an important ecological explanation. Plants with immature fruits -without viable seeds- have high phenol and proanthocyanidin contents that act as deterrent compounds to prevent their consumption by insects and herbivores, whereas ripe fruits have attractive colors (anthocyanins and other pigments) and a sweet taste to stimulate their consumption by herbivores and the consequent dispersion of seeds (Parr and Bolwell, 2000).

The increase in TP after blush (light red) is distinctive to maqui fruit because the species mentioned above show a steady decrease in phenol content during fruit development and maturity. No significant differences in the FT between the different maturity stages of maqui could mean that the FT is not a good indicator of maqui fruit ripeness.

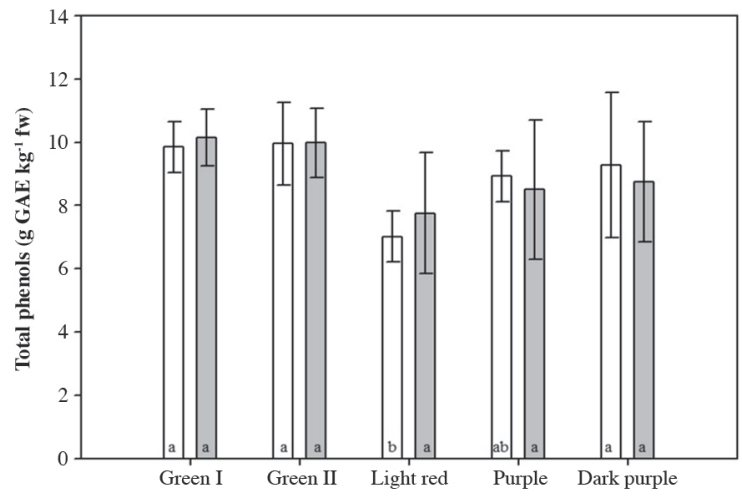

Vertical bar (Paredones in white and Rancagua in gray) represents mean and standard deviation of five individuals. Means in each bar (Paredones and Rancagua) not followed by the same letter are significantly different $(\mathrm{p} \leq 0.05)$

GAE: gallic acid equivalent.

Figure 3. Total phenols content of maqui fruits during fruit development and maturation. 
TP content showed a high dispersion in each maqui fruit sampling site which could be explained by the different individuals (or genotypes) where fruit samples were obtained. Maqui is a dioecious plant with cross pollination (Montenegro, 2002); therefore a high variability of genotypes may be observed in a wild population. As mentioned above the genotype is one of the main factors affecting the content of polyphenols in fruits. This means that within the same species significant differences in the types and content of phenolic compounds have been described (Fan-Chiang et al., 2005; Scalzo et al., 2005; Reyes-Carmona et al., 2005; Lohachoompol et al., 2008; Speisky et al., 2008). Total phenols content is also affected by different environments in which plants grow (Parr and Bolwell, 2000; Gambelli y Santaroni, 2004; Reyes-Carmona et al., 2005). For this reason, in this study the TP content in both Paredones and Rancagua had no important differences due to similar climatic conditions of both sampling sites in the given growing season.

\section{Total anthocyanins during maqui fruit development and maturation}

Quantification of anthocyanins is mainly achieved either colorimetrically or by high-performance liquid chromatography (HPLC). The principal method is the $\mathrm{pH}$ differential method, widely used in industry, because it is a rapid and easily performed procedure (Giusti and Wrolstad, 2001). However, this method cannot provide any information regarding the compositional profile of anthocyanins and the relative amounts of these compounds. In accordance with fruit color, first (green I) and second (green II) stages of maturity did not contain anthocyanins (under the method conditions of this study). Starting at the light red stage, TA increased significantly during fruit maturity for both sampling sites (Figure 4). The highest increase was observed between the light red and purple stages. These changes are similar to other berry fruits

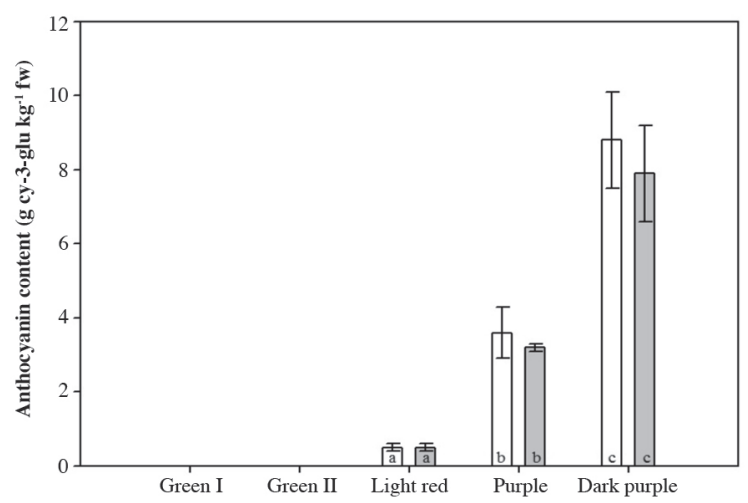

Vertical bar (Paredones in white and Rancagua in gray) represents mean and standard deviation of five individuals. Means in each bar (Paredones and Rancagua) not followed by the same letter are significantly different $(\mathrm{p} \leq 0.05)$.

g cy -3-glu: cyanidin-3-glucoside.

Figure 4. Total anthocyanin content of maqui fruits during fruit development and maturation. (cranberry, pomegranate, blackberry, and red raspberry) where color development and sugar accumulation (SS) have been associated with the increase in anthocyanin pigment (Siriwoharn et al., 2004; Kulkarni and Aradhya, 2005; Celik et al., 2008; Tosun et al., 2008; Wang et al., 2009). The late stage of maturity showed the highest TA for both Paredones (8.82 $\mathrm{g} \mathrm{cy}^{-3}$-glu kg-1 $\mathrm{fw}$ ) and Rancagua (7.87 $\mathrm{g} \mathrm{cy}^{-3}-\mathrm{glu} \mathrm{kg}^{-1} \mathrm{fw}$ ), and this late maturity stage also had the highest SS. Within the environment, air temperature is the main factor influencing anthocyanin content in fruits (Downey et al., 2006) and comparable air temperatures at both sampling sites could explain similar results for Paredones and Rancagua in the given growing season.

The high anthocyanin content of maqui fruit can also be attributed to its high surface/volume ratio. In botanical terms maqui fruit corresponds to a berry (fruit with multiple seeds, with a fleshy mesocarp and endocarp that comes from a superior ovary flower [Bowling, 2000]) and this kind of fruit accumulates anthocyanins mainly in the epicarp (peel) (Ghafoor et al., 2010; 2011; Wang et al., 2012).

\section{Antioxidant activity during maqui fruit development and maturation}

Polyphenols are scavengers of a wide variety of reactive species such as superoxide, hydroxyl radical, peroxyl radical, hypochlorous acid, and peroxynitrous acid, resulting in less reactive radicals (Wang and Jiao, 2000; Mertz et al., 2009). Different methods exist to evaluate the AA (Gil et al., 2000; Mermelstein, 2008), both in vitro or in vivo. The FRAP method measures the reduction of ferric ion $\left(\mathrm{Fe}^{3+}\right)$ to ferrous ion $\left(\mathrm{Fe}^{2+}\right)$ in the presence of antioxidants (Benzie and Strain, 1996). In this study the AA by FRAP method showed similar behavior to TP (Figure 5), as AA decreased during the first maturity stages and increased after the light red stage. Nevertheless, the highest FRAP values were observed in the late maturity

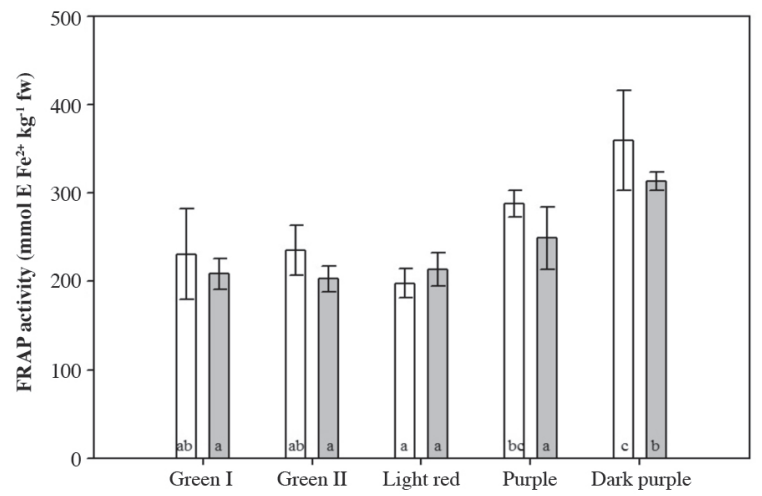

Vertical bar (Paredones in white and Rancagua in gray) represents mean and standard deviation of five individuals. Means in each bar (Paredones and Rancagua) not followed by the same letter are significantly different (at $\mathrm{p} \leq 0.05$ ). FRAP: ferric reducing ability of plasma assay.

Figure 5. Antioxidant activity measured by FRAP activity of maqui fruits during fruit development and maturation. 
stage (dark purple) showing the great AA of maqui fruit. This result is different in comparison to other berry fruits where immature fruit has higher AA than mature fruit (Kulkarni and Aradhya, 2005; Celik et al., 2008; Pothitirat et al., 2009; Wang et al., 2009). The structureactivity relationship of flavonoids has been documented in hydrophilic systems, showing that the antioxidant activity depends on TP content and the type of polyphenols (structural features). In maqui fruit, anthocyanin-rich fraction accounts for most of its antioxidant properties (Miranda-Rottmann et al., 2002), explaining that the highest AA is related to the highest TA.

In this study maqui fruits from the deep purple stage had higher AA for both Paredones (359.7 mmol E Fe ${ }^{2+}$ $\mathrm{kg}^{-1} \mathrm{fw}$ ) and Rancagua (313.6 mmol $\mathrm{E} \mathrm{Fe}^{2+} \mathrm{kg}^{-1} \mathrm{fw}$ ) than previous studies (Araya et al., 2006) probably because different extraction methods were used.

The results of this study are accordant with other studies for berry fruits where it is evident that flavonoid biosynthesis is tightly associated with the development stages of the fruit and where ripening of fruits is related with the highest soluble solid and anthocyanin content (Vvedenskaya and Vorsa, 2004; Kulkarni and Aradhya, 2005; Arena and Curvetto, 2008; Celik et al., 2008; Rodarte Castrejón et al., 2008).

\section{CONCLUSION}

The changes in fruit size, soluble solid (SS), color and antioxidant content of maqui fruit explained their growth, development, and maturity. The maturation in maqui fruit is expected $91 \mathrm{~d}$ after fruit set in Central Chile (December) according to this study as well as observation in the wild. The high variability of results of total phenol (TP), total anthocyanins (TA), and antioxidant activity (AA) was predictable due to the differences between the five individuals selected from the wild in each sampling site. This denotes a clear major difference between genotypes rather than climatic (air temperature) conditions. The present results revealed for the first time that the maturation and ripening processes in maqui fruit appeared to have a significant effect on phenolic composition (TA) and the corresponding AA and showed different behavior than other fruits recognized as berries. This distinctive behavior in maqui fruit corresponds to the highest AA observed in the latest stage of harvest (dark purple). Finally, SS and TA appear as good indicators of the ripeness in maqui fruit in this study and they could be used as parameters of maturity index.

\section{ACKNOWLEDGEMENT}

CONICYT Grant to pursue doctoral studies in Chile. FONDECYT Grant 1110808. We thank María Eugenia Muñoz (Agrícola Las Rosas) and Ernesto Bacigalupo (Frutícola Ramirana) for their help in sample collection.
Contenidos de polifenoles $y$ actividad antioxidante de maqui (Aristotelia chilensis [Molina] Stuntz) durante el desarrollo y maduración de frutos en Chile Central. El maqui (Aristotelia chilensis [Molina] Stuntz, Elaeocarpaceae) es una especie nativa de Chile que produce unas bayas pequeñas que se recolectan principalmente de individuos silvestres. Los beneficios para la salud atribuidos a los frutos de maqui se deben a sus altos contenidos de polifenoles, así como a la gran variedad de antocianos y flavonoles. Uno de los principales factores que afectan el contenido de polifenoles en frutos es el estado de madurez a la cosecha. El objetivo de este estudio fue determinar el contenido de fenoles totales, antocianos totales y la actividad antioxidante (método FRAP [habilidad del plasma para reducir el hierro férrico]) de frutos de maqui cosechados en diferentes estados de madurez de dos poblaciones silvestres ubicadas en Chile Central. Cada estado de madurez fue caracterizado de acuerdo a los días desde la cuaja de frutos, tamaño y sólidos solubles. El contenido de fenoles totales disminuyó mientras que el contenido de antocianos totales aumentó desde fruto verde hasta fruto en pinta; sin embargo, los valores de ambas variables aumentaron desde pinta hasta fruto púrpura oscuro. La mayor capacidad antioxidante se observó en los frutos del último estado de madurez analizado (púrpura oscuro). Los resultados demostraron que la madurez de consumo en frutos de maqui puede ser esperada con 1100 grados día de crecimiento (91 d después de cuaja) en Chile Central. En este momento de cosecha, frutos con sólidos solubles entre 18 y $19{ }^{\circ}$ Brix tienen los mayores contenidos de antocianos y actividad antioxidante (FRAP). Este estudio constituye los primeros avances en el entendimiento de la maduración de frutos de maqui y su correspondiente actividad antioxidante.

Palabras clave: antocianos totales, estados de madurez, fenoles totales, FRAP, madurez de consumo.

\section{LITERATURE CITED}

Araya, H., C. Clavijo, y C. Herrera. 2006. Capacidad antioxidante de frutas y verduras cultivadas en Chile. Archivos Latinoamericanos de Nutrición 56:361-365.

Arena, M.E., and N. Curvetto. 2008. Berberis buxifolia fruiting: Kinetic growth behavior and evolution of chemical properties during the fruiting period and different growing seasons. Scientia Horticulturae 118:120-127.

Benzie, I.F.F., and J.J. Strain. 1996. The ferric reducing ability of plasma (FRAP) as a measure of "antioxidant power": the FRAP assay. Analytical Biochemistry 239:70-76.

Bowling, B.L. 2000. The berry grower's companion. 284 p. Timber Press, Portland, Oregon, USA.

Brown, P.N., S.J. Murch, and P. Shipley. 2012. Phytochemical diversity of cranberry (Vaccinium macrocarpon Aiton) cultivars by anthocyanin determination and metabolomic profiling with chemometric analysis. Journal of Agricultural and Food Chemistry 60:261-271.

Capocasa, F., J. Scalzo, B. Mezzetti, and M. Battino. 2008a. Combining quality and antioxidant attributes in the strawberry: The role of genotype. Food Chemistry 111:872-878. 
Celik, H., M. Özgen, S. Serce, and C. Kaya. 2008. Phytochemical accumulation and antioxidant capacity at four maturity stages of cranberry fruit. Scientia Horticulturae 117:345-348.

Céspedes, C., M. El-Hafidi, N. Pavon, and J. Alarcon. 2008. Antioxidant and cardioprotective activities of phenolic extracts from fruits of Chilean blackberry Aristotelia chilensis (Elaeocarpaceae), Maqui. Food Chemistry 107:820-829.

Céspedes, C.L., M. Valdez-Morales, J.G. Avila, M. El-Hafidi, J. Alarcón, and O. Paredes-López. 2010. Phytochemical profile and the antioxidant activity of Chilean wild black-berry fruits, Aristotelia chilensis (Mol.) Stuntz (Elaeocarpaceae). Food Chemistry 119:886-895.

Cuevas-Rodríguez, E.O., G.G. Yousef, P.A. García-Saucedo, J. López-Medina, O. Paredes-López, and M.A. Lila. 2010. Characterization of anthocyanins and proanthocyanidins in wild and domesticated Mexican blackberries (Rubus spp.) Journal of Agricultural and Food Chemistry 58:7458-7464.

Dirnbock, T., J. Greimler, P. Lopez, and T.F. Stuessy. 2003. Predicting future threats to the native vegetation of Robinson Crusoe Island, Juan Fernandez Archipelago, Chile. Conservation Biology 17:1650-1659.

Downey, M.O., N.K. Dokoozlian, and M.P. Krstic. 2006. Cultural practice and environmental impacts on the flavonoid composition of grapes and wine: A review of recent research. American Journal of Enology and Viticulture 57:257-268.

Escribano-Bailón, M.T., C. Alcalde-Eon, O. Muñoz, J.C. RivasGonzalo, and C. Santos-Buelga. 2006. Anthocyanins in berries of maqui (Aristotelia chilensis (Mol.) Stuntz). Phytochemical Analysis 17:8-14.

Fan-Chiang, H-J., and R.E. Wrolstad. 2005. Anthocyanin pigment composition of blackberries. Journal of Food Science 70:C198-C202.

Fredes, C. 2009. Antioxidants in Chilean native berries. Boletín Latinoamericano y del Caribe de Plantas Medicinales y Aromáticas 8:469-478.

Gajardo, R. 1994. La vegetación natural de Chile. Clasificación y distribución geográfica. 165 p. Editorial Universitaria, Santiago, Chile.

Gambelli, L., and G.P. Santaroni. 2004. Polyphenols content in some Italian red wines of different geographical origins. Journal of Food Composition and Analysis 17:613-618.

Ghafoor, K., J. Park, and Y.H. Choi. 2010. Optimization of supercritical fluid extraction of bioactive compounds from grape (Vitis labrusca B.) peel by using response surface methodology. Innovative Food Science \& Emerging Technologies 11:485-490.

Ghafoor, K., F. Al-Juhaimi, and Y.H. Choi. 2011. Effects of grape (Vitis labrusca B.) peel and seed extracts on phenolics, antioxidants and anthocyanins in grape juice. Pakistan Journal of Botany 43:1581-1586.

Gil, M.A., F.A. Tomás-Barberán, B. Hess-Pierce, D.M Holcroft, and A.A. Kader. 2000. Antioxidant activity of pomegranate juice and its relationship with phenolic composition and processing. Journal of Agricultural and Food Chemistry 48:4581-4589.

Giusti, M.M., and R.E. Wrolstad. 2001. Anthocyanins. Characterization and measurement with UV-visible spectroscopy In Wrolstad R.E. (ed.) Current protocols in food analytical chemistry. Wiley Editorial, New York, USA.

Gómez, P., S. Hahn, y J. San Martin. 2009. Estructura y composición florística de un matorral bajo plantaciones de Pinus radiata D. Don en Chile Central. Gayana Botánica 66:256-268.

Kulkarni, A.P., and S.M. Aradhya. 2005. Chemical changes and antioxidant activity in pomegranate arils during fruit developmental. Food Chemistry 93:319-324.

Lohachoompol, V., M. Mulholland, G. Srzednicki, and J. Craske. 2008. Determination of anthocyanins in various cultivars of highbush and rabbiteye blueberries. Food Chemistry 111:249-254

Matthei, O. 1995. Manual de malezas que crecen en Chile. 545 p. Alfabeta Impresores, Santiago, Chile.

Mermelstein, N.H. 2008. Determining antioxidant activity. Food Technology 11:63-66.
Mertz, C., A. Gancel, Z. Gunata, P. Alter, C. Dhuique-Mayer, F. Vaillant, et al. 2009. Phenolic compounds, carotenoids and antioxidant activity of three tropical fruits. Journal of Food Composition and Analysis 22:381-387.

Miranda-Rottmann, S., A. Aspillaga, R. Pérez, L. Vasquez, F. Martínez, and F. Leighton. 2002. Juice and phenolic fractions of the berry Aristotelia chilensis inhibit LDL oxidation in vitro and protect human endothelial cells against oxidative stress. Journal of Agricultural and Food Chemistry 50:7542-7547.

Montenegro, G. 2002. Chile nuestra flora útil. 267 p. $2^{\text {a }}$ ed. Pontificia Universidad Católica de Chile, Santiago, Chile.

Parr, A.J., and G.P. Bolwell. 2000. Phenols in the plant and in man The potential for possible nutritional enhancement of the diet by modifying the phenols content or profile. Journal of the Science of Food and Agriculture 80:985-1012.

Pliszka, B., J. Wazbinska, and G. Huszcza-Ciolkowska. 2009. Polyphenolic compounds and bioelements in fruits of eastern teaberry (Gaultheria procumbens L.) harvested in different fruit maturity phases. Journal of Elementology 14:341-348.

Pothitirat, W., M.T. Chomnawang, R. Supabphol, and W. Gritsanapan. 2009. Comparison of bioactive compounds content, free radical scavenging and anti-acne inducing bacteria activities of extracts from the mangosteen fruit rind at two stages of maturity. Fitoterapia 80:442-447.

Reyes-Carmona, J., G.G. Yousef, R.A. Martínez-Peniche, and M.A Lila. 2005. Antioxidant capacity of fruits extracts of blackberry (Rubus sp.) produced in different climatic regions. Journal of Food Science 70(7):S497-S503.

Rodarte Castrejón, A.D., I. Eichholz, S. Rohn, L.W. Kroh, and S Huyskens-Keil. 2008. Phenolic profile and antioxidant activity of highbush blueberry (Vaccinium corymbosum L.) during fruit maturation and ripening. Food Chemistry 109:564-572.

Rodríguez, R.R., O.S. Matthei, and M.M. Quezada. 1983. Flora arbórea de Chile. 408 p. Editorial de la Universidad de Concepción, Concepción, Chile.

Rojo, L.E., D. Ribnicky, S. Logendra, A. Poulev, P. Rojas-Silva, et al. 2012. In vitro and in vivo anti-diabetic effects of anthocyanins from Maqui Berry (Aristotelia chilensis). Food Chemistry 131:387-396

Scalzo, J., A. Politi, N. Pellegrini, B. Mezzetti, and M. Battino. 2005. Plant genotype affects total antioxidant capacity and phenolic contents in fruit. Nutrition 21:207-213.

Schreckinger, M.E., J. Wang, G. Yousef, M.A. Lila, and E. Gonzalez de Mejia. 2010. Antioxidant capacity and in vitro inhibition of adipogenesis and inflammation by phenolic extracts of Vaccinium floribundum and Aristotelia chilensis. Journal of Agricultural and Food Chemistry 58:8966-8976.

Singleton, V.L., and J.A. Rossi, Jr. 1965. Colorimetry of total phenolics with phosphomolybdic-phosphotungstic acid reagents American Journal of Enology and Viticulture 16:144-158.

Siriwoharn, T., R.E. Wrolstad, C.E. Finn, and C.B. Pereira. 2004 Influence of cultivar, maturity, and sampling on blackberry (Rubus L. hybrids) anthocyanins, polyphenolics, and antioxidant properties Journal of Agricultural and Food Chemistry 52:8021-8030.

Speisky, H., A. Peña, M. Gómez, C. Fredes, M. Hurtado, M Gotteland, and O. Brunser. 2008. Antioxidants in Chilean berries Acta Horticulturae (ISHS) 777:485-492.

Tosun, I., N.S. Ustun, and B. Tekguler. 2008. Physical and chemical changes during ripening of blackberry fruits. Scientia Agricola 65:87-90.

Vvedenskaya, I.O., and N. Vorsa. 2004. Flavonoid composition over fruit development and maturation in American cranberry, Vaccinium macrocarpon Ait. Plant Science 167:1043-1054.

Wang, S.Y., M.J. Camp, and M.K. Ehlenfeldt. 2012. Antioxidant capacity and alpha-glucosidase inhibitory activity in peel and flesh of blueberry (Vaccinium spp.) cultivars. Food Chemistry 132:1759-1768.

Wang, S.Y., C-T. Chen, and C.Y. Wang. 2009. The influence of light and maturity on fruit quality and flavonoid content of red raspberries. Food Chemistry 112:676-684. 
Wang, S.Y., and H. Jiao. 2000. Scavenging capacity of berry crops on superoxide radicals, hydrogen peroxide, hydroxyl radicals, and singlet oxygen. Journal of Agricultural and Food Chemistry 48:5677-5684.

Wang, S.Y, and H-S. Lin. 2000. Antioxidant activity in fruits and leaves of blackberry, raspberry, and strawberry varies with cultivar and developmental stage. Journal of Agricultural and Food Chemistry 48:140-146.
Wrolstad, R.E. 1976. Color and pigment analyses in fruit products. Oregon State University Agricultural Experimental Station Bulletin 624:1-17. 